\title{
Evaluation of Land Suitability for Irrigation Development and Sustainable Land Management Using ArcGIS on Katar Watershed in Rift Valley Basin, Ethiopia
}

\author{
Megersa Adugna Gurara \\ Department of Water Resource and Irrigation Engineering, School of Water Resource and Environmental Engineering, Haramaya Institute of \\ Technology, Haramaya University, Harar, Ethiopia
}

Email address:

megeadu2006@gmail.com

\section{To cite this article:}

Megersa Adugna Gurara. Evaluation of Land Suitability for Irrigation Development and Sustainable Land Management Using ArcGIS on Katar Watershed in Rift Valley Basin, Ethiopia. Journal of Water Resources and Ocean Science. Vol. 9, No. 3, 2020, pp. 56-63.

doi: $10.11648 /$ j.wros.20200903.11

Received: March 23, 2020; Accepted: April 17, 2020; Published: August 19, 2020

\begin{abstract}
Evaluating land suitability from the available land and water resources potential for irrigation development is very important for planning sustainable use of limited land and water resources. The critical objective of this study was to evaluate the suitable land resource potential for irrigation development for the Katar River watershed in the Rift Valley Basin in Ethiopia by using ArcGIS based on Multi-Criteria Evaluation (MCE) techniques. The steps undertaken were watershed delineation, characterizing the watershed by suitability parameters such as slope, soil texture, soil depth, drainage classes, proximity to river and urban, and land use land cover. And then, re-classification and mapping according to suitability classification, identification of irrigable land, and estimation of surface water potential and irrigation water requirements were followed. After reclassified, the suitability analyses of the each parameter were classified based on suitability classes for irrigation development. The weighting analysis of all parameters resulted that $34.08 \%$ was classified as high suitable (S1), $58.08 \%$ moderately suitable (S2), 3.8\% marginally suitable (S3), whereas $3.21 \%$ not suitable (N) for surface irrigation development. Finally, comparing the required gross irrigation water requirement and available monthly flow of the River, the River has the capacity for the fulfilling irrigation water demand to irrigate command area of the watershed during dry season.
\end{abstract}

Keywords: Land Suitability, Irrigation Potential, Slope Suitability, Water Availability, ArcGIS, Katar Watershed

\section{Introduction}

Water resources management through irrigation development in agriculture is a critical contributor to the economic and social development [1]. Though irrigation in Africa has the potential to enhance agricultural productivities by at least $50 \%$, agricultural system on the continent is totally rainfed [2]. Irrigation development has been recognized as a key tool to encourage economic growth and rural development, and is considered as a root of food security and eradicating poverty in developing countries [3]. Reference [4] evaluated the role of irrigation to the Ethiopian economy and revealed that the gross margin from irrigation is $219.7 \%$ higher than the gross margin from rainfed agriculture. Therefore, irrigation development supplies additional irrigation water to agriculture areas, so users can obtain higher yields than they could without irrigation that increase cropping intensity.

Ethiopia is situated between $3^{\circ} \mathrm{N}$ and $15^{\circ} \mathrm{N}$ latitudes and $33^{\circ} \mathrm{E}$ to $48^{\circ} \mathrm{E}$ longitudes. Ethiopia is a landlocked country, with a land area of 1.13 million $\mathrm{km}^{2}$, found in Eastern Africa [1]. Ethiopia has above 80 million population and is the second most populous country in Africa next to Nigeria [1]. Utmost percentage of the total population in Ethiopia live in highland areas, with $85 \%$ being rural and dependent on agriculture with a low level of productivity [1].

The country has plenty of land and water resources potential for irrigation development $[1,5]$. The surface water resource potential is impressive but, little developed [6]. Reference [7]estimated that total irrigable land potential in the country is 5.3 Mha, including 1.6 Mha through rainwater harvesting and groundwater however, the estimated irrigation 
coverage is about 640,000 ha including small, medium and large schemes. From this potential, about $3.74 \%$ is the Rift valley basin potential [1]. Irrigation development is playing a great role in adapting to climate change, achieving food security, and improving household incomes. But, due to technical, financial, management and other problems the country hasn't utilized its potential very well up to today [810]. However, there has been concern regarding the improvement of irrigation expansion and management of existing irrigation schemes but the result is not much satisfactory.

Evaluating available land resources for irrigation is important for planning their sustainable use [11-13]. The irrigation potential can be evaluated by using an integration of Multi-Criteria Decision Analysis in ArcGIS weight overlay principle [14-17]. In the study area, there is no sustainable land resource utilization and management and its agricultural system has been dependent on rainfed agriculture and does not yet fully beneficiary. This outcome from the lack of updated information on available resources potential, systematic potential assessment, and matching of the available water resources potential with crop water requirements of the area. So far, there was no study conducted in this area concerning irrigation potential assessment. Therefore, the main intention of this study was to evaluate the irrigation potential based on river discharge and land suitability in the Katar watershed level which will contribute to the overall objective of achieving sustainable socioeconomic development through the equitable utilization of and benefits from the river water and land resource development.

\section{Materials and Methods}

\subsection{Description of the Study Watershed}

The irrigation suitability study was conducted for Katar watershed found in South - Eastern part of Ethiopia in Oromia regional state, Arsi Zone at about $180 \mathrm{~km}$ of Addis Ababa. The watershed is situated in the northern watersheds of the Rift Valley basin. It located between $7022^{\prime}-8009^{\prime} \mathrm{N}$ latitudes and 380 50'- 390 24' E longitude as shown in Figure 1. It covers a total drainage area of $3231.59 \mathrm{~km}^{2}$ in the Rift Valley basin. According to rainfall data collected from the meteorological stations inside and near to the area, the annual rainfall of the study area is averagely estimated to $1298 \mathrm{~mm}$ where the lower rainfall was recorded in months, October to April in all stations.

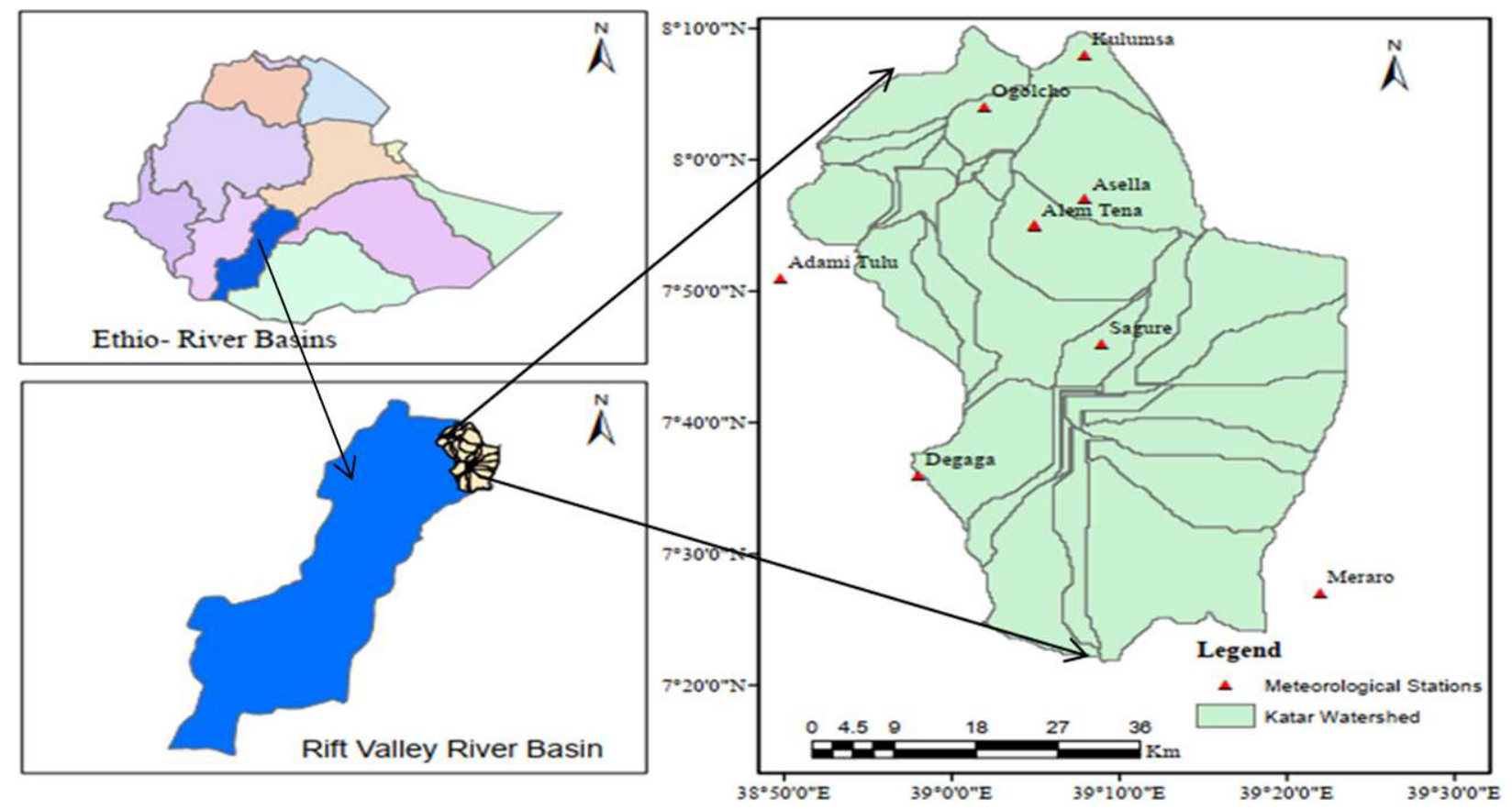

Figure 1. Location of the Study Area.

\subsection{Data Collection and Analysis}

The data required for this particular study includes climate data; soil and land use the land cover map. The required meteorological data such as all climate data were collected from the National Meteorological Agency (NMA) of Ethiopia used as input in CROPWAT software. Whereas, Soil and land use data were obtained from the Ethiopian Ministry of Water, Irrigation and Electricity (EMWIE).

Reference evapotranspiration (ETo): CROPWAT 8.0 computer program was used to estimate the total water requirements of major crops grown in the study area. This program uses the Penman-Monteith equation to calculate reference evapotranspiration (ETo) [18]. The water needs of crops are directly related to the surrounding climatic parameters and crop coefficient.

Crop evapotranspiration (ETc): ETc is the depth (quantity) of water required by the crop to meet its evapotranspiration losses and the water used for metabolic processes [18]. Then, the crop evapotranspiration (ETc) was calculated using the 
equation.

$$
\mathrm{ETc}=\mathrm{ETo}^{*} \mathrm{Kc}
$$

Where; $\mathrm{ETc}=$ crop evapotranspiration $(\mathrm{mm} /$ day $)$.

$\mathrm{ETo}=$ Reference crop evapotranspiration $(\mathrm{mm} /$ day);

$\mathrm{Kc}=$ Crop coefficient (fraction), varies with a crop growing stages

Irrigation water requirement (IWR): The irrigation water requirement of crops is the part of the water requirement of crops that should be satisfied by irrigation and computed as equation stated below.

$$
\mathrm{IWR}=\mathrm{ETc}-\mathrm{RFeff}
$$

Where, $\mathrm{ETc}=$ crop evapotranspiration $(\mathrm{cm}) ; \mathrm{IWR}=$ irrigation water requirement $(\mathrm{cm})$ and $\mathrm{RFeff}=$ effective rainfall $(\mathrm{cm})$.

\subsection{Methods}

In the Katar watershed, potential land suitable for irrigation using surface water was estimated by the Weighted Overlay tool of ArcGIS Spatial Analyst Toolbox based on Multi-Criteria Evaluation decision (MCE) techniques. The land suitability was evaluated by developing and assigning weight to the key factors [19] that affect the irrigation potential of the land from Surface water potential. The factors considered under this study were adopted from different kinds of literature $[12,14,16,17,20-26]$ such as physical land features (LULC, soil types and slope derived from DEM of the sub-river basin), climate characteristics, river proximity and market access.

Finally, the reclassified and weighted factor maps are overlain and a preliminary surface irrigation area suitability map is computed by the Weighted Overlay tool of ArcGIS Spatial Analyst Toolbox.

\subsection{Determination of Land Suitable for Surface Irrigation Potential}

The land suitability for surface irrigation potential was identified by considering physical land factors; such as slope, soil texture, soil depth, drainage classes, land use, and land cover and water resources availability [14, 16, 27]. After the individual suitability of each factor was analyzed, potentially irrigable land was predicted by weighting overlay analysis of those factors.

\subsubsection{Slope Suitability}

The slope map was derived from DEM with by application of spatial analysis tools (surface analysis) in ArcGIS. The slope derived from the DEM was classified into four suitability classes (S1, S2, S3, and N) depending upon [28] for surface irrigation development in the aid of the "Reclassification" tool function in ArcGIS. Accordingly, the slope suitability factor ratings identified as $0-2 \%$ is $\mathrm{S} 1,2-5 \%$ is $\mathrm{S} 2,5-8 \%$ is $\mathrm{S} 3$ and $>8 \%$ is classified as $\mathrm{N}$ (not) suitable class. After the slope was classified accordingly, the area of each slope was calculated in the attribute table and the geographical location of each slope suitability map was identified using ArcGIS tools.

\subsubsection{Soil Suitability}

Agricultural land is of worth only because of its ability to produce crops. Most evaluations are based on factors that affect this ability to provide production. The basic soil physical properties used for evaluation of soil suitability for surface irrigation were soil drainage, soil texture, and soil depth $[29,30]$. The soil suitability was evaluated, using FAO/UNESCO-soil map of East Africa. In the study area, seven types of soil were identified and analyzed as indicated in figure 2. The area coverage of each soil was calculated in the attribute table after converting into polygon format.

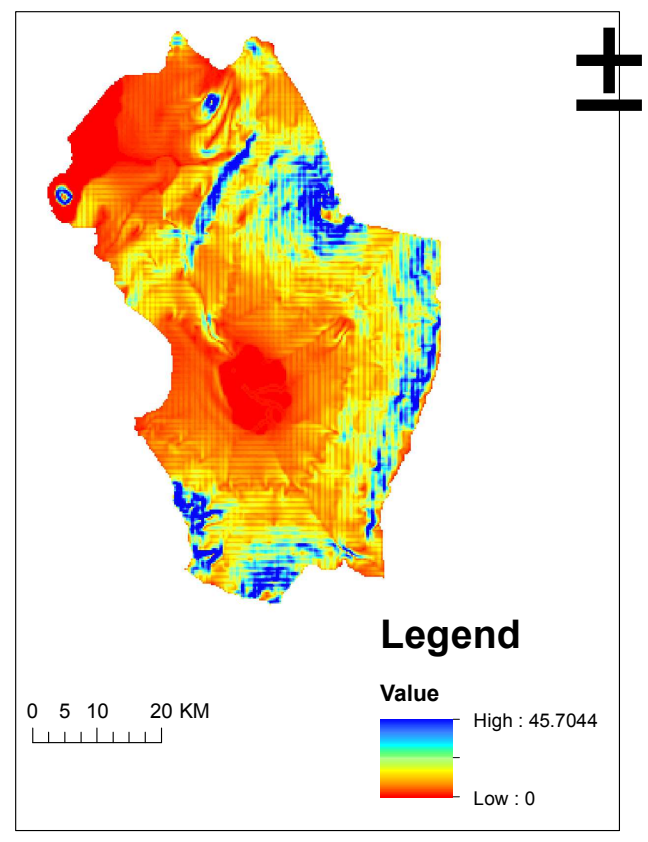

Figure 2. Slope condition of the study area.

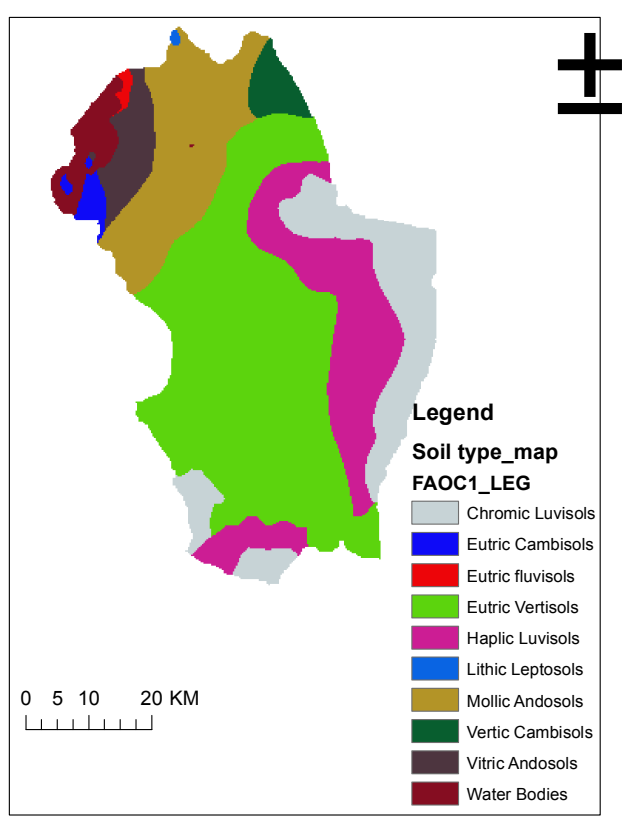

Figure 3. Soil type of the Katar watershed. 
The identified soil types in figure 3 with the respective areas were classified based on suitability rating class guidelines adopted shown in table 1 . Other physical factors that affect land suitability for surface irrigation development are river proximity, road proximity, and market access. The suitability class of a land parcel concerning market access, road and river proximity is determined by its distance about the road network, a large town, and perennial rivers. The distances were calculated by projecting the locations to a UTM Mercator Zone $37 \mathrm{~N}$. After classifying and mapping the distance into four classes of equal ranges, the closer distances were classified as $\mathrm{S} 1$ and farthest distances were in class S4 [21].

Table 1. Soil suitability factor rating for irrigation suitability.

\begin{tabular}{lllll}
\hline \multirow{2}{*}{ Factors } & \multicolumn{4}{l}{ Suitability factor class rating } \\
\cline { 2 - 5 } & S1 & S2 & S3 & N \\
\hline Drainage class & Well & Imperfect & Poor & Very poor \\
Soil depth & $>200$ & $100-140$ & $50-100$ & $<50$ \\
Soil texture & L-SiCL, C & SiL, SCL & SL & Si-L \\
\hline
\end{tabular}

\subsubsection{Land Use and Land Cover Suitability}

The land use land cover map of the Katar River sub-basin was clipped from Rift valley basin land use the land cover map. Accordingly, six types of land use land cover classes of the area were identified as bare land, cultivated land, grass land, shrub grassland, forest land, and habitant and water body. The rasterized land use/cover map of these LULC classes was categorized into four suitability classes $(\mathrm{S} 1, \mathrm{~S} 2 . \mathrm{S} 3$, and $\mathrm{N})$ and used in the suitability class to investigate potentially irrigable sites combined with other factors. The geographical location of each LULC is shown in Figure 4.

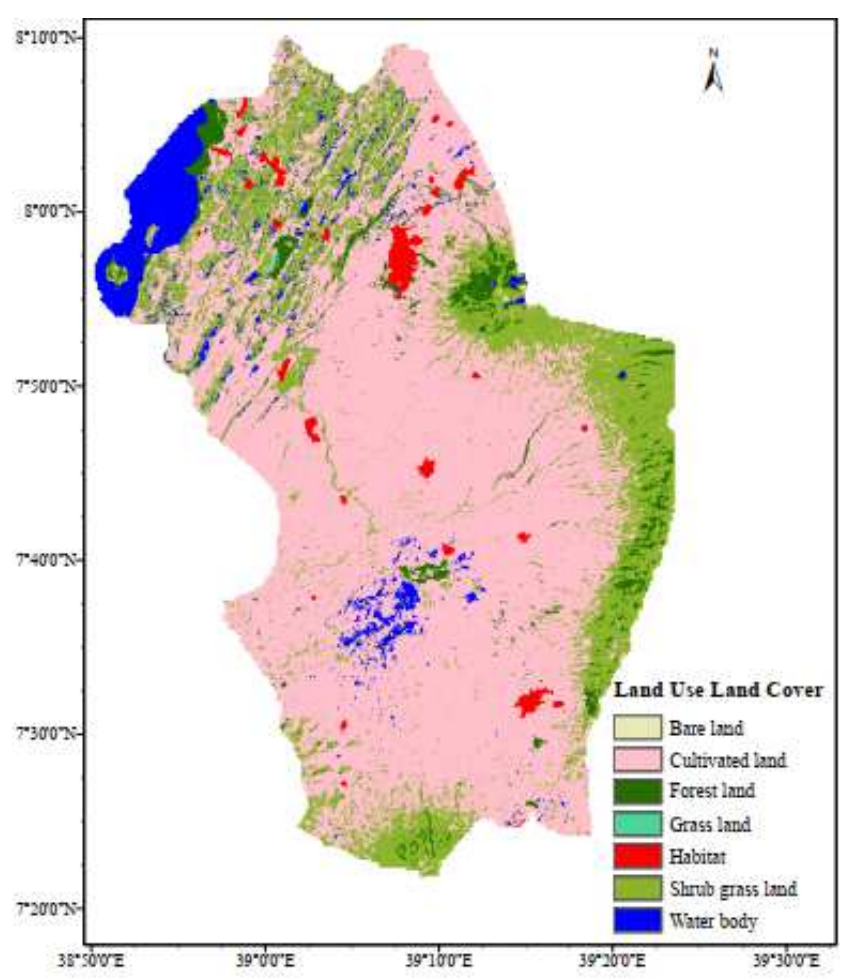

Figure 4. Land Use Land Cover of the Watershed.

\subsection{Evaluation of Irrigable Site}

The rasterized and reclassified maps of each parameter (slope, soil texture, soil depth, drainage class, land use land cover) were overlaid together to produce one suitability map for surface irrigation. During the weighted overlay, the evaluation scale of 1 to 4 was used, 1 represents highly suitable, 2 moderately suitable, 3 marginally suitable and 4 represents unsuitable areas.

The high percent of influence was given for slope during the weighted overlay analysis since the slope was the determinant factor in evaluating the land for surface irrigation development. Once each factor was converted into raster then, it was weighted in weighted overlay analysis function in a GIS environment. Lastly, the suitability rating was given as $\mathrm{S} 1, \mathrm{~S} 2, \mathrm{~S} 3$, and $\mathrm{N}$, as well as each area suitability rating, were calculated and then, the map of irrigable land was produced. These overall works of land suitability estimation were done in the ArcGIS environment.

\subsection{Surface Water Potential Availability}

Information about streamflow data was collected and required for estimation of the discharge of water available for surface water irrigation applications during the dry season phase. The low flows were calculated for the Katar River with daily averaged discharges for the years 1990-2007. The daily discharge data were obtained from the Ethiopian Ministry of Water, Electricity and Energy.

The irrigation potential for dominant crops in the watershed was computed. Finally, the irrigation potential of surface water was estimated as the ratio of surface water availability to the total crop water requirement of the dominant crops. The streamflow (discharges) of Katar River that was gauged and obtained from the Ethiopian Ministry of Water, Irrigation, and Electricity was used directly to compute surface irrigation potential and compared with gross irrigation water requirements.

\section{Results and Discussion}

The analyses results of the factors considered for land suitability evaluation for surface irrigation development are presented in the following sections.

\subsection{Slope Suitability Evaluation}

The slope is a key factor affecting land suitability for irrigation, particularly surface irrigation. It has high impacts on drainage, erosion, irrigation efficiency, cost of land development, size of fields', labors requirements, range of crops selection, etc. Per the slope analysis in ArcGIS, the slope of the study areas was classified into four suitability classes (S1, S2, $\mathrm{S} 3$, and N) based on the suitability classes and the final slope suitability map developed as shown in Figure 5.

The slope analyses indicate that about $41.34 \%$ of the watershed was covered with less than $2 \%$ slope class and $93.13 \%$ was covered with less than $8 \%$ slope class where this land classified under highly suitable to marginally suitable for 
surface irrigation. A slope class of greater than $8 \%$ was only $6.87 \%$ of the watershed area which is permanently not suitable for irrigation. According to slope suitability classification for surface irrigation, most of the area of the Katar River watershed was found to be suitable for surface irrigation regarding its work efficiency and cost for land leveling, canal construction, and value for the saving pumping system.

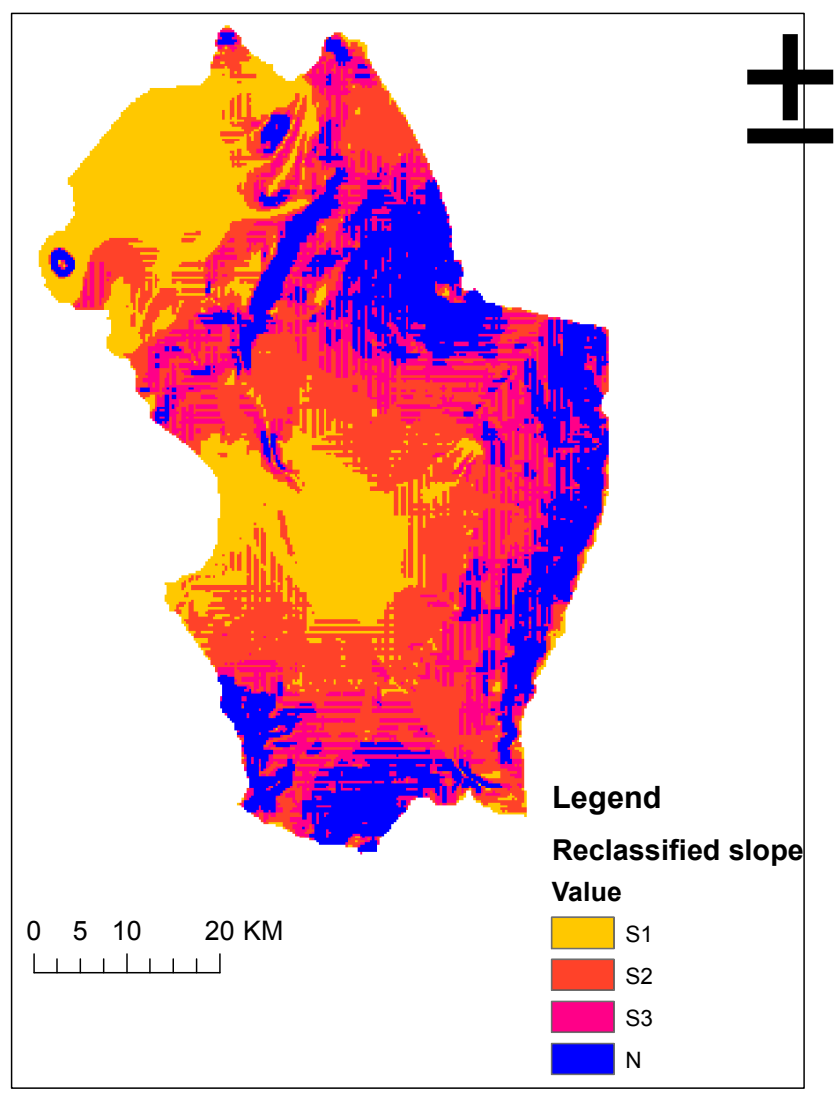

Figure 5. Reclassified slope suitability map of the watershed.

\subsection{Soil Suitability Evaluation}

The final evaluated soil suitability for irrigation indicating based on soil suitability factors such as soil texture, depth, drainage and proximity to river and urban after reclassification and overlaid in the figure 6.

The first class highly suitable (S1) was characterized by clay to clay loam soil texture, greater than $2 \mathrm{~m}$ soil depth and the excellent soil drainage in figure 6 . It covered $34.91 \%$ of the total area coverage of the study area. The second suitability class is moderately suitable classes (S2). It covered $58.08 \%$ in the study area and is comprised of soil type having soil texture clay loam to sand clay loam, with a soil depth of 1.4 to $1 \mathrm{~m}$, and moderate soil drainage. Their reasonable drainage condition limits these soil types while the other factors are optimum for surface irrigation.

The third suitability class covered around $3.8 \%$ of the total area of the watershed having sandy loam, with a soil depth of $100-50 \mathrm{~cm}$ and moderate soil drainage were classified as S3 (marginally suitable). Lastly, the fourth suitability class covered $3.21 \%$ of the total area coverage of the study area.
They were constrained by shallow soil depth and water bodies while other factors were optimum for surface irrigation. In overall, majority soils of the Katar river watershed were found to be suitable for surface irrigation.

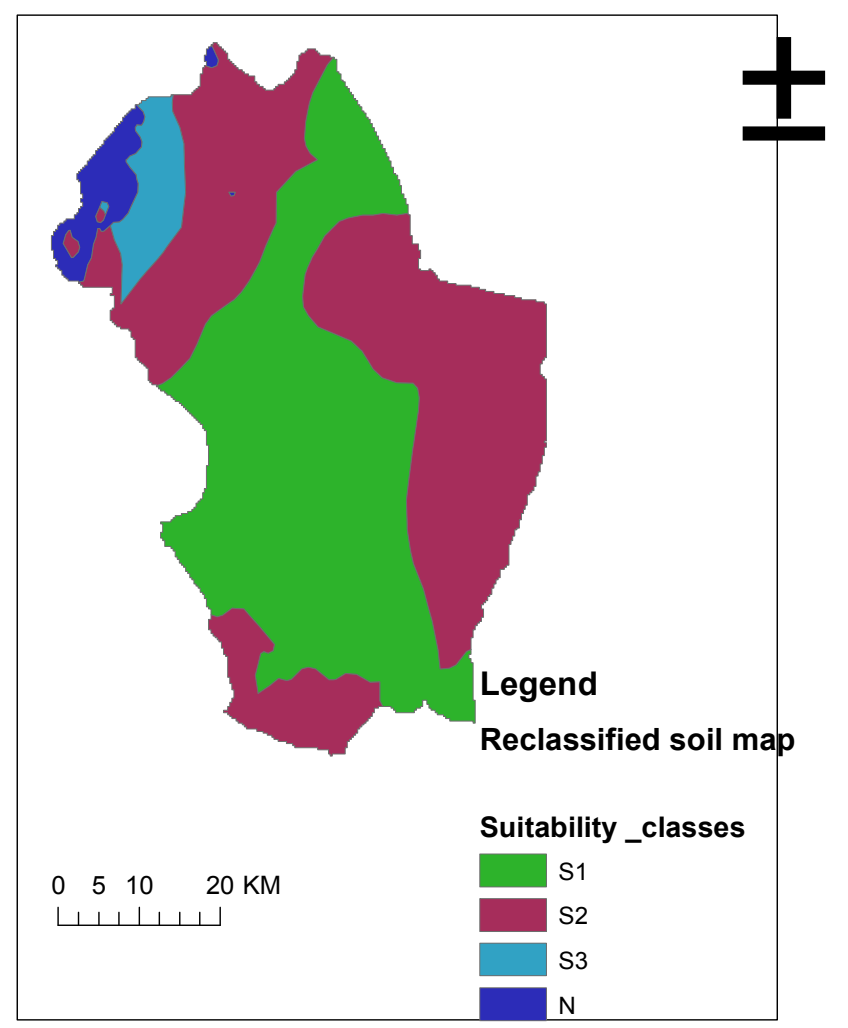

Figure 6. Reclassified soil suitability.

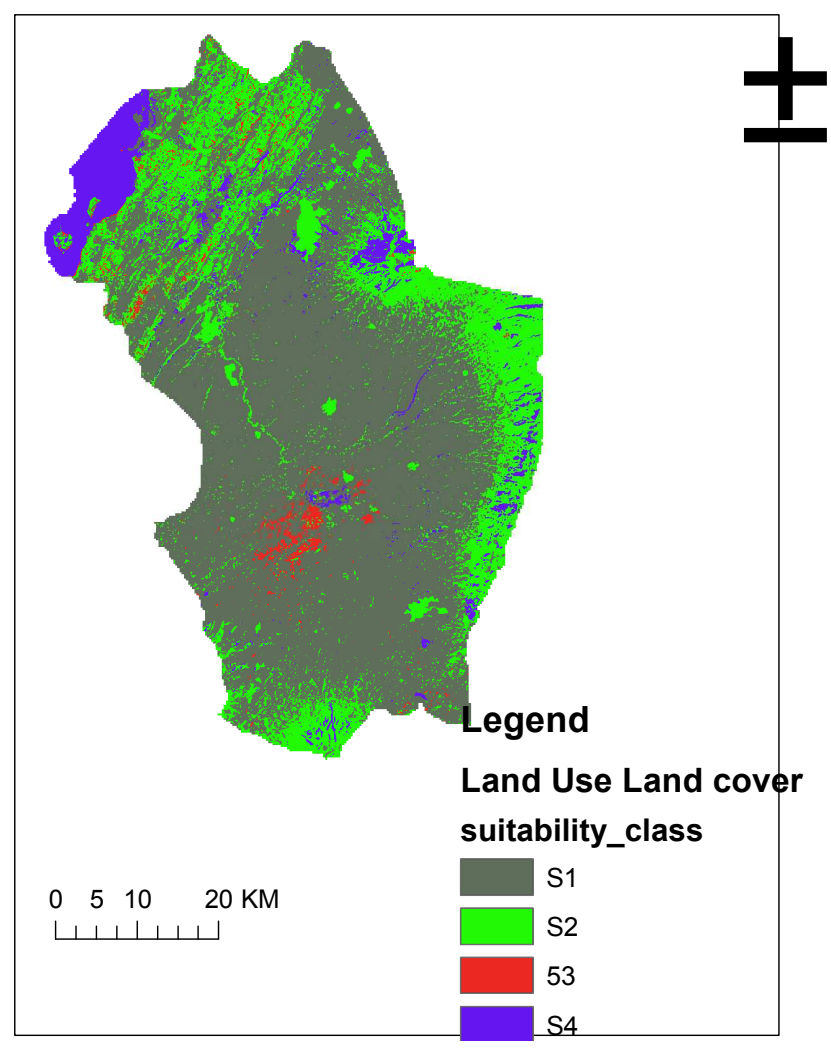

Figure 7. Reclassified land use land cover suitability map. 


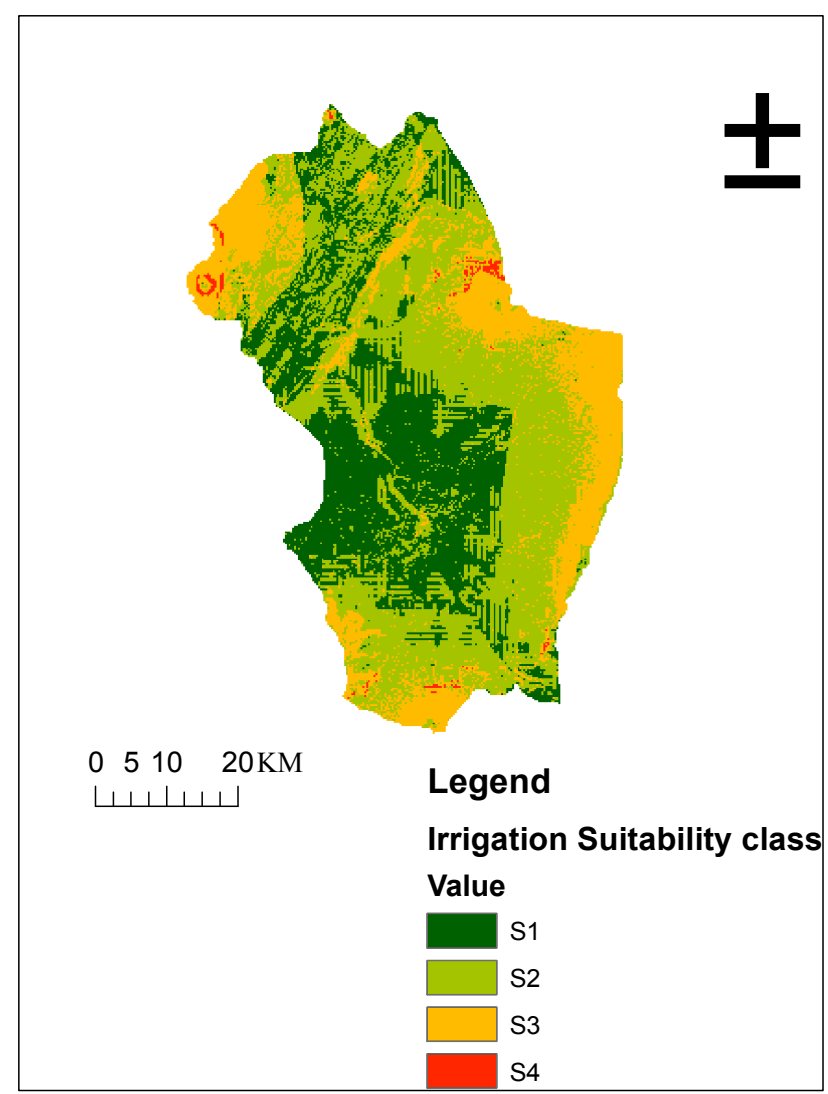

Figure 8. Overlaid irrigation suitability map.

\subsection{Land Use Land Cover Suitability Evaluation}

Seven primary land-use and land-cover classes were recognized per ArcGIS analysis. The suitability of Land use/cover types for irrigation potential were ranked based on working efficiency, costs to land preparing for cultivation and environmental impacts. The cultivated land was classified as highly suitable for irrigation from Land use/cover classes with the assumption that these land cover classes could be irrigated without or with the limited cost for land clearing and farm preparation. It covered $61.03 \%$ of the study area. According to the agricultural practice, grassland area classified as the second suitable area next to the cultivated land for irrigation development. On the other hand, wood and shrub land classified as lands marginally suitable (S3) for irrigation. These are due to their work efficiency, the cost for land clearing and land preparation, whereas dense forest, habitat, and water bodies were classified as lands not suitable $(\mathrm{N})$ for irrigation. This land cover classes were $7.76 \%$ of the total land cover of the study area they are constrained to use for irrigation in figure 7.

\subsection{Suitable Land for Irrigation Development}

Potentially irrigable land was evaluated based on the specified suitable criteria by creating irrigation suitability model analysis which involved weighting of values of all data sets such as soil texture, drainage, depth, slope, proximity to river and proximity to urban and land use/cover. From the total area coverage of the study area $34.08 \%$ was classified as high suitable (S1), 58.08\% moderately suitable (S2), 3.8\% marginally suitable (S3), whereas $3.21 \%$ not suitable $(\mathrm{N})$ for surface irrigation development in figure 8 .

Areas suitable for irrigation vs. surface water availability

After mapping the suitable land for irrigation based on suitability criteria, it is essential to check the irrigation water availability throughout the year for crops production by irrigation in the study area especially during the dry season. Irrigation potential of the river sub-basin obtained by dividing the gross irrigation water demand of the dominant crops grown in the study area to the average monthly flows of the Katar River.

A potential evaporation rate was calculated by Penman Moenteith approach to calculate the crop water requirement and it ranges from $2.89 \mathrm{~mm}$ in July to $3.94 \mathrm{~mm}$ in April. The total crop water requirement computed on a monthly basis ranges from $0.96 \mathrm{~mm} /$ day in the rainy season to a maximum of $4.43 \mathrm{~mm} /$ day. Finally, the computed gross irrigation water requirement by considering $50 \%$ irrigation efficiency is less than the available monthly flow through the river at a dry time by considering 50\% downstream demand in figure 9 .

The irrigation potential of the 50 percent available water is computed by dividing the available water to the total gross crop water requirement. The result indicated the land potential of the area is very small relative to the available surface water potential of the Katar river watershed. Generally, the river potential is higher in all months than the gross irrigation requirement so that the river is potentially adequate to irrigate the potential area without storage provided.

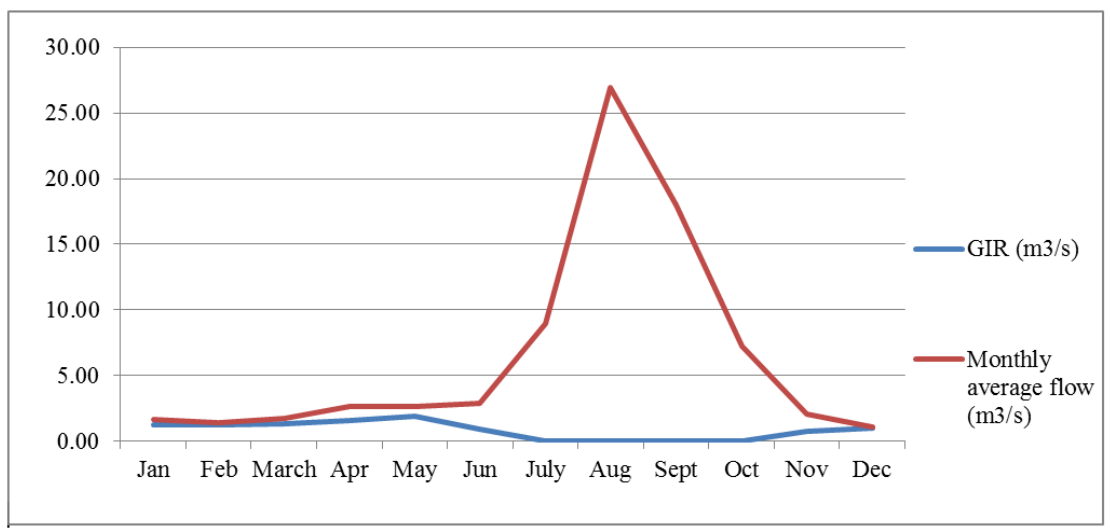

Figure 9. The gross irrigation requirement (GIS) vs. the monthly average river flow. 


\section{Conclusion}

The overall result indicates that the available average monthly river flow was potentially suitable and sufficient for irrigation development in the watershed. Utmost above half of the watershed area was potentially suitable for irrigation based on the weighted overlaid result map of slope, soil texture, soil depth, drainage class and land use/cover map.

Generally, comparing gross monthly irrigation demand of identified irrigable land under river sub-basin with corresponding 50\% available monthly river flows, the river flow discharge is higher in all months than the required discharge; so that the river is potentially adequate to fulfill the demand without requirement of storage structure by considering half of the River flow discharge for downstream users.

\section{References}

[1] S. B. Awulachew, A. D. Yilma, M. Loulseged, W. Loiskandl, M. Ayana, and T. Alamirew, Water Resources and Irrigation Development in Ethiopia, no. January. 2007.

[2] L. You et al., "What is the irrigation potential for Africa? A combined biophysical and socioeconomic approach," Food Policy, vol. 36, no. 6, pp. 770-782, 2011.

[3] MoA, "Small-Scale Irrigation Situation Analysis and Capacity Needs Assessment:," Natural Resources Management Directorate, no. October. p. 44, 2011.

[4] F. Hagos, G. Makombe, R. Namara, and S. Awulachew, Importance of Irrigated Agriculture to the Ethiopian Economy: Capturing the direct net benefits of irrigation, vol. 128, no. 1 . 2009.

[5] B. Berhanu, Y. Seleshi, and A. M. Melesse, "Surface water and groundwater resources of Ethiopia: Potentials and challenges of water resources development," in Nile River Basin: Ecohydrological Challenges, Climate Change and Hydropolitics, vol. 9783319027203, Springer International Publishing, 2014, pp. 97-117.

[6] FAO, “Aquastat: Ethiopia.” pp. 1-14, 2005.

[7] S. B. Awulachew and M. Ayana, "Performance OF irrigation: An assessment at different scales in ethiopia," Exp. Agric., vol. 47, no. S1, pp. 57-69, 2011

[8] Z. Agide et al., "Analysis of water delivery performance of smallholder irrigation schemes in Ethiopia: Diversity and lessons across schemes, typologies and reaches," LIVES Work. Pap. 15, no. 15, p. 38, 2016.

[9] G. G. Haile, "Irrigation in Ethiopia, a review," J. Environ. Earth Sci., vol. 3, no. 10, pp. 264-269, 2015.

[10] S. B. Awulachew, A. D. Yilma, and E. Africa, "Statues quo analysis, Characterization and Assessment of Performance of Irrigation in Ethiopia Seleshi B. Awulachew and Aster Denekew Yilma," pp. 2-13.

[11] F. T. Berhe, A. M. Melesse, D. Hailu, and Y. Sileshi, "MODSIM-based water allocation modeling of Awash River Basin, Ethiopia," Catena, vol. 109. Elsevier B. V., pp. 118-
128, 2013.

[12] M. Abraham, H. Daniel, N. Abeba, D. Tigabu, G. Temesgen, and G. Hagos, "GIS Based Land Suitability Evaluation for Main Irrigated Vegetables in Semaz Dam, Northern Ethiopia," vol. 4, no. 3. pp. 158-163, 2015.

[13] B. Mandal, G. Dolui, and S. Satpathy, "Land suitability assessment for potential surface irrigation of river catchment for irrigation development in Kansai watershed, Purulia, West Bengal, India," Sustainable Water Resources Management, vol. 4, no. 4. Springer International Publishing, pp. 699-714, 2018.

[14] W. Negash, "Gis Based Irrigation Suitability Analysis (a Case Study of Abaya-Chamo Basin, Southern Rift Valley of Ethiopia)," Lake Abaya Research Symposium 2004 Proceedings, no. 2000. pp. 79-89, 2004.

[15] A. Wale, T. H. M. Rientjes, A. S. M. Gieske, and H. A. Getachew, "Ungauged catchment contributions to Lake Tana' s water balance," vol. 3693, no. April, pp. 3682-3693, 2009.

[16] A. Mendas and A. Delali, "Integration of MultiCriteria Decision Analysis in GIS to develop land suitability for agriculture: Application to durum wheat cultivation in the region of Mleta in Algeria," Computers and Electronics in Agriculture, vol. 83. Elsevier B. V., pp. 117-126, 2012.

[17] Y. Chen, J. Yu, and S. Khan, "Spatial sensitivity analysis of multi-criteria weights in GIS-based land suitability evaluation," Environmental Modelling and Software, vol. 25, no. 12. pp. 1582-1591, 2010.

[18] R. G. Allen, L. S. Pereira, D. Raes, and M. Smith, "Determination of $\mathrm{ET}_{0}$, crop evapotranspiration," Guidel. Comput. Crop Water Requir. Irrig. Drain. Pap. 56, p. 309, 1998.

[19] A. Ceballos-Silva and J. López-Blanco, "Delineation of suitable areas for crops using a Multi-Criteria Evaluation approach and land use/cover mapping: A case study in Central Mexico," Agricultural Systems, vol. 77, no. 2. pp. 117-136, 2003.

[20] Mahari A. \& Alebachew A., "Land Suitability Evaluation for Irrigation in Dejen District, Ethiopia," International Journal of Scientific and Research Publications, vol. 3, no. 9. pp. 9-11, 2013.

[21] A. W. Worqlul, A. S. Collick, D. G. Rossiter, S. Langan, and T. S. Steenhuis, "Assessment of surface water irrigation potential in the Ethiopian highlands: The Lake Tana Basin," Catena, vol. 129. pp. 76-85, 2015.

[22] H. Yohannes and T. Soromessa, "Land suitability assessment for major crops by using GIS-based multi-criteria approach in Andit Tid watershed, Ethiopia," Cogent Food \& Agriculture, vol. 4, no. 1. Cogent, 2018.

[23] T. Yitbarek, "Physical Land Suitability Evaluation for Irrigation in the Lower Alwero River Area of Abobo, Western Ethiopia," American Journal of Agriculture and Forestry, vol. 5, no. 3. p. 60, 2017.

[24] C. Wale and T. S. Realistic, "Realistic assessment of irrigation potential in the Lake Tana basin, Ethiopia Realistic assessment of irrigation potential in the lake Tana basin, Ethiopia," Iwmi, no. July. pp. 9-10, 2013. 
[25] J. K. JOSHUA, N. C. ANYANWU, and A. J. AHMED, "Land suitability analysis for agricultural planning using GIS and multi criteria decision analysis approach in Greater Karu Urban Area, Nasarawa State, Nigeria," African Journal of Agricultural Science and Technology (AJAST), vol. 1, no. 1. pp. 14-23, 2013.

[26] Ayalew G., "Land Suitability Evaluation for surface and sprinkler irrigation Using Geographical Information System (GIS) in Guang Watershed, Highlands of Ethiopia," Journal of Environment and Earth Science, vol. 4, no. 22. pp. 140-150, 2014.
[27] N. GT, T. AD, and T. AF, "Irrigation \& Drainage Systems Engineering Irrigation Potential Assessment on Shaya River Sub-Basin in Bale Zone," Irrigat Drainage Sys Eng., vol. 8, no. 1. pp. 1-7, 2019.

[28] M. Bousquet, K. Frenken, L. Verelst, and W. D. Division, "Assessment of irrigation potential in Africa." pp. 115-126, 1995.

[29] FAO, "Irrigation in Figures - AQUASTAT Survey 2005." pp. $1-14,2006$.

[30] FAO, "Guidelines for Intergrated Planning for Sustainable Management of Land Resources.” p. 88, 1999. 